\title{
LOGISTICS OF WASTE MANAGEMENT IN HEALTHCARE INSTITUTIONS
}

\author{
Halina Marczak \\ 1 Institute of Transport, Internal Combustion Engines and Ecology; Mechanical Faculty, Lublin University of \\ Technology, Nadbystrzycka 36, 20-618 Lublin, Poland, e-mail: h.marczak@pollub.pl
}

Received: 2016.03.09

Accepted: 2016.06.01

Published: 2016.07.01

\begin{abstract}
The waste management system in health care is a tool that allows to conduct reasonable steps to reduce their amount, collection, storage and transport, and provide a high level of utilization or disposal. Logistics solutions in waste management are intended to make full use of the infrastructure and technical resources, optimize costs, ensure the safety and health at work and meet legal requirements. The article discusses the elements of the logistics system of waste management in hospital, necessary to ensure the smooth flow of waste from its origin to landfilling. The following criteria were characterized: technical and technological, ecological and economic that can be used in the analysis and evaluation of solutions in waste management in the hospital. Finally, solutions to improve waste management system in the hospital on the example of the real object have been presented.
\end{abstract}

Keywords: logistics of waste management, medical waste, non-medical waste, hospital waste, optimization of the waste management system.

\section{INTRODUCTION}

Logistics of waste management generated in healthcare institutions is a chain of operations related to the movement of waste from its origin to recovery or disposal. The purpose of waste management logistics is the prevention of environment pollution by eliminating improper waste management and protection of natural resources as well as quantitative protection by replacing them with recyclable materials. Along with ecological purposes, waste management logistics is committed to the task of reducing the costs associated with collection, storage and transportation of waste. The article presents logistics solutions in hospital waste management in the aspect of legal requirements [Marszelewski 2014, Project ... 2015] and proposals for measures to improve the effectiveness of these solutions.

\section{RESEARCH PURPOSE AND METHODOLOGY}

The primary aim of the study was to present the elements of the logistics of waste man- agement in hospital treatment, quantitative and qualitative analysis of waste streams and possible solutions to improve the process. In the discussion, information and figures in the field of waste management in the Independent Public Clinical Hospital No. 4 in Lublin [Collection... 2015] and own research were used.

\section{ELEMENTS OF THE LOGISTICS SYSTEM OF WASTE MANAGEMENT IN HOSPITAL}

When creating a logistics system of waste management one should bear in mind its functional, instrumental and institutional dimensions. Functional dimension allows to consider waste management as complex tasks and activities in the area of the entire business unit. The instrumental dimension includes the selection of appropriate instruments of planning, monitoring and control activities in waste management. Institutional dimension allows the placement of the waste management system in the organizational structure of the entity and to identify those responsible for waste management. A feature of the waste management system is also its rela- 
tionship with companies involved in waste recycling and disposal. The elements of logistics system of waste management in medical facilities shown in Figure 1.

While organizing the system one should relate in particular to three criteria of waste management: ecological, economic and technological. Each element of the system must be analyzed in terms of these criteria. Table 1 shows selected elements of waste management system of medical services including selection criteria for solutions in waste management.

The implementation of the system of logistics of waste is intended to enable separate collection and storage of waste to be effective and compatible with legal requirements [Suchecka,

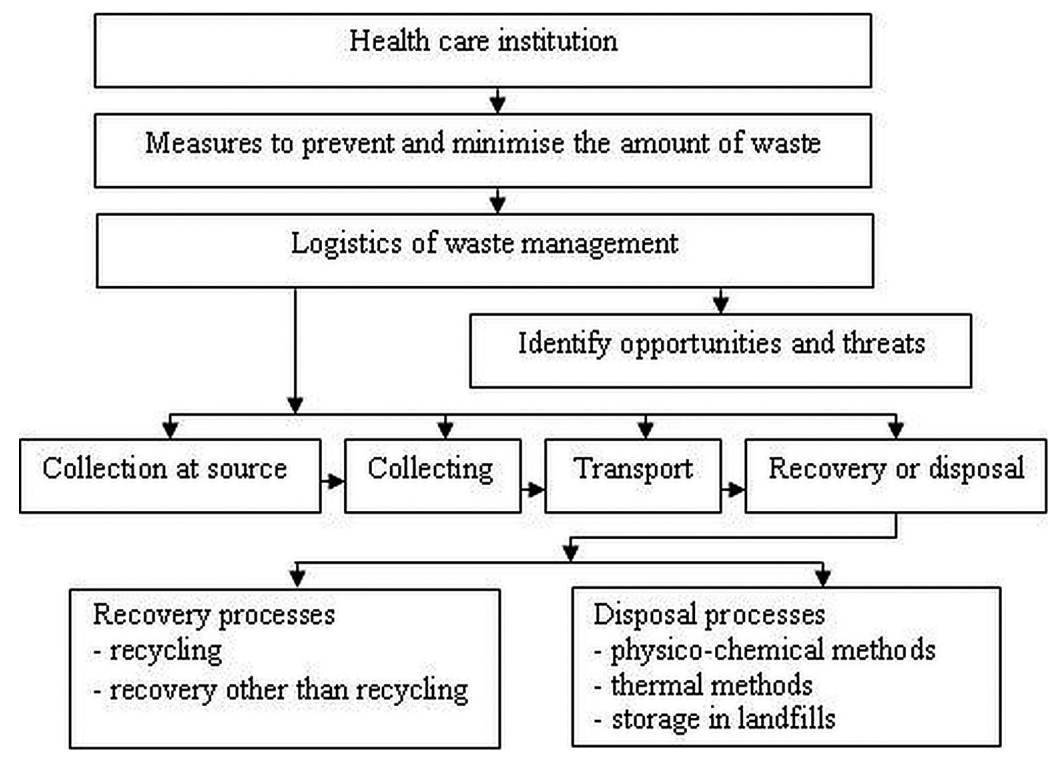

Figure 1. Elements of the logistics system of waste management in health care institutions

Table 1. Criteria for the analysis and evaluation of solutions in hospital waste management

\begin{tabular}{|c|c|c|c|}
\hline \multirow{2}{*}{$\begin{array}{c}\text { Element of the } \\
\text { system }\end{array}$} & \multicolumn{3}{|c|}{ Criteria } \\
\hline & Technological & Ecological & Economic \\
\hline $\begin{array}{l}\text { Collection } \\
\text { „at source” }\end{array}$ & $\begin{array}{l}\text { Solutions should include: } \\
\text { a) the intended method of usable } \\
\text { waste management } \\
\text { b) the place and methods of } \\
\text { permitted medical waste disposal, } \\
\text { i.e. independently by the waste } \\
\text { producer or through a third party. }\end{array}$ & $\begin{array}{l}\text { Principles of collection must } \\
\text { comply with the guidelines set } \\
\text { out in the Act on Waste [12] and } \\
\text { Regulation of the Minister of } \\
\text { health [4]. }\end{array}$ & $\begin{array}{l}\text { The cost of waste collection is } \\
\text { influenced by: } \\
\text { a) the solutions adopted in the field } \\
\text { of waste management } \\
\text { b) the accuracy of sorting (sorting } \\
\text { into multiple fractions) } \\
\text { c) solutions adopted in reducing the } \\
\text { volume of waste collected. }\end{array}$ \\
\hline Collecting & $\begin{array}{l}\text { The solutions depend on: } \\
\text { a) the handling of waste suitable for } \\
\text { use, i.e. whether the producer of } \\
\text { recyclable materials will transfer } \\
\text { them to recycling entities or they } \\
\text { will be treated as municipal waste } \\
\text { b) the place and permitted methods } \\
\text { of medical waste disposal, i.e. } \\
\text { independently by the waste } \\
\text { producer or through a third party. }\end{array}$ & $\begin{array}{l}\text { Rules of temporary storage } \\
\text { of medical waste, hazardous } \\
\text { and non-hazardous waste in } \\
\text { accordance with the guidelines } \\
\text { set out in the Act on Waste [12] } \\
\text { and Regulation of the Minister of } \\
\text { health [4]. }\end{array}$ & $\begin{array}{l}\text { Preparation of optimal infrastructure } \\
\text { for the collection of waste. The } \\
\text { use of the waste press and, as a } \\
\text { result, reduction of the required } \\
\text { storage space (press-containers, } \\
\text { balers). Increasing the level of cost } \\
\text { recovery and disposal of waste } \\
\text { through more accurate sorting } \\
\text { (modular containers for recyclable } \\
\text { fractions). }\end{array}$ \\
\hline Transport & $\begin{array}{l}\text { Internal transport of hazardous } \\
\text { medical waste in transport } \\
\text { equipment intended solely for } \\
\text { this purpose. External transport } \\
\text { of hazardous waste in specialist } \\
\text { transport. }\end{array}$ & $\begin{array}{l}\text { Solutions to prevent the } \\
\text { formation of the risks associated } \\
\text { with damage to the containers or } \\
\text { bags during transport and ensure } \\
\text { proper hygienic condition of the } \\
\text { means of transport. } \\
\text { The use of disposal installations, } \\
\text { which are located closest to the } \\
\text { source of waste. }\end{array}$ & $\begin{array}{l}\text { Solutions to minimize the } \\
\text { external costs of transport } \\
\text { a) the use of press or balers to } \\
\text { reduce the volume of recyclables } \\
\text { and selling them to entities using } \\
\text { recyclable waste } \\
\text { b) the use of press-conatiners to } \\
\text { reduce the volume of mixed } \\
\text { municipal waste } \\
\text { c) storage within the time allowed } \\
\text { to enable a reduction in the } \\
\text { frequency of waste collection. }\end{array}$ \\
\hline
\end{tabular}


Twardowska 2014]. Proper classification and segregation of waste is a prerequisite to achieve a higher level of waste recovery.

The issue of classification and segregation of waste should be considered separately for the group of medical waste (listed in the catalogue of waste in group 18 [Regulation... 2014]) and for the group of non-medical waste generated in the hospital [Marszelewski 2014]. Medical waste differentiates the infectious waste (including waste classification codes $180102^{*}, 180103^{*}, 180180^{*}$, $180182^{*}$ ), hazardous waste other than infectious waste (codes $180106^{*}, 180108^{*}, 180110^{*}$ ) and other (codes 180101, 180104, 180107, 180109, 180181) [Regulation... 2014].

In the classification and segregation of medical waste it is important that infectious waste are classified as only those wastes which have been in contact with patients or contain alive germs. Organizing the collection of infectious waste at source, one should use solutions that prevent accidental mixing them with other waste.

Hazardous medical waste other than infectious, should be classified on the basis of substances contained in them. Other medical waste includes waste that does not pose epidemiological or chemical risk. The collection of waste should arranged to isolate the waste whose recovery is permissible (Table 2) [Regulation... 2015].

In addition to medical waste, the waste management system includes also municipal waste. Fractions of recyclable uncontaminated waste should be separately collected and transported, preferably directly to the recycling plants. From the sale of recyclable materials waste producer can reap the financial benefits. An important task is to improve waste management solutions which can produce the maximum amount of useful waste fractions and reduce their volume at the stage of collecting. These actions relate to packaging waste from paper and cardboard, plastics, glass, multi-material (e.g. blister) and metals. In order to reduce the volume of the waste it is possible to use presses, including balers. Concentrated waste occupy less storage space, ensure optimum use of cargo space vehicles and reduce transportation costs of waste.

The logistics of waste management should facilitate the proper management of organic kitchen waste (with meal preparation and post-consumer waste). The overriding principle is the selective collection of waste, and then transferring them directly or through transport companies to the entities involved in organic recycling. For current densification of organic waste press-containers can be used.

The framework of municipal waste generated in the hospital also includes the tasks of collection of mixed waste. The choice of containers for their collection should be preceded by the analysis of the profitability of options considered. The use of press-containers for the collection of waste reduces the volume of waste and thus reduces the cost of their transportation.

Smooth functioning of the waste management system is guaranteed by appropriate scheduling the tasks and their strict implementation. The tasks in the field of medical waste management in the hospital include:

1) Collecting waste from wards and other organizational units of the hospital in a determined sequence and frequency (usually 2 times a day) and their transport to temporary collection places. Keeping quantity record of waste according to wards and other organizational units.

2) Presence during weighing and loading of waste into trucks which transport waste to the disposal facilities. Filling the document confirming the receipt of the waste, "waste transfer cards". The collection frequency of medical waste in accordance with the contract and legal requirements (e.g. waste collection type $180102^{*}-3$ or 6 times a week).

3) Current maintenance of waste storage facilities.

4) Disinfection and cleaning of storage rooms or refrigeration equipment for storage of waste after each removal of infectious waste.

Table 2. Types of medical waste whose recovery is permissible [Regulation... 2015]

\begin{tabular}{|c|l|}
\hline Code of waste & \multicolumn{1}{c|}{ Type of waste } \\
\hline 180101 & Surgical instruments (without contact with the infectious agent) \\
\hline 180104 & Non-infectious waste (e.g. dressing material, plaster, linen, disposable clothing) \\
\hline $180106^{*}$ & Chemicals, including chemicals, containing hazardous substances \\
\hline 180107 & Chemicals, including chemicals, which do not contain hazardous substances \\
\hline ex $180110^{*}$ & Dental amalgam waste (excluding infectious waste) \\
\hline ex 180181 & Worn peloids after the treatments, other than dangerous - postoperative muds \\
\hline
\end{tabular}


5) Washing storage rooms or refrigeration facilities after each removal of dangerous medical waste other than infectious.

The tasks in the field of non-medical waste include: 1) Collection of separately collected waste in a sequence from organizational units of the hospital. In the case of compaction and baling of recyclable materials (paper and cardboard, plastics) current service equipment crushing. Keeping a quantity record of waste by organizational units of the hospital.

2) Internal transport of recyclables to the place of storage.

3) Presence during weighing useful waste to storage based on the "waste transfer card".

4) Reception of unsorted municipal waste in a sequence of organizational units of the hospital. Internal transport of waste to the storage containers (container, press-containers).

5) Washing and maintaining waste trucks and trolleys.

\section{PROPOSALS TO OPTIMIZE WASTE MANAGEMENT SYSTEM IN THE HOSPITAL ON THE EXAMPLE OF A REAL OBJECT}

As a result of activities in the Clinical Hospital No. 4 in Lublin medical and non-medical wastes are generated. Waste management in the hospital is systemic. A significant impact on the functioning of the system is imposed by technical means, infrastructure and economic opportunities available to the company. The solutions should be constantly improved to increase the efficiency of the system.

Medical waste is separately collected in their origin. The estimated quantities of medical waste for the period of May 2015 - May 2016 are summarized in Table 3. Medical waste is received at a specified frequency and thermally disposed of by the Company Eco-Top o.o. in Rzeszów.

Increasing the frequency of waste collection reduces the amount of waste stored temporarily. However, it causes an increase in transportation costs. It is economically reasonable for the hospital to reduce the frequency of disposing medical waste coded as $180103^{*}$ and $180182^{*}$. According to the law, these wastes can be stored at a temperature of $10^{\circ} \mathrm{C}$ to $18^{\circ} \mathrm{C}$ for $72 \mathrm{~h}$ and at a temperature below $10^{\circ} \mathrm{C}-30$ days [Project... 2015, Regulation... 2010]. The implementation of such a solution would require taking measures for the temporary storage of larger quantities of waste than before. In practice, this may mean the need for investment in infrastructure and technical means. A lower frequency of waste collection reduces the number of vehicles on the road, which translates into a reduction in congestion, accidents and the risk of formation of harmful impact to the environment.

Non-medical waste generated in hospital, collected selectively include mixed municipal waste (code 200301), the dry fraction of municipal waste (code 200199), waste from greenery maintenance biodegradable (code 200201), textiles (code 200111), bulky waste (code 200307), paper documents to be destroyed (code 200101), waste from renovation and construction (codes 170101 and 170107), waste batteries and accumulators

Table 3. Estimated quantities of medical waste generated in the hospital for a 12-month period

\begin{tabular}{|c|l|c|c|}
\hline $\begin{array}{c}\text { Code of } \\
\text { waste }\end{array}$ & \multicolumn{1}{|c|}{ Type of waste } & $\begin{array}{c}\text { Amount of } \\
\text { waste [Mg] }\end{array}$ & Frequency of collection \\
\hline 180101 & $\begin{array}{l}\text { Surgical instruments (without contact with the infectious } \\
\text { agent) }\end{array}$ & 1.5 & Followed by telephone order \\
\hline $180102^{*}$ & $\begin{array}{l}\text { Body parts and organs including blood bags and } \\
\text { preservatives used for its storage }\end{array}$ & 5.5 & 3 times a week \\
\hline $180103^{*}$ & Other wastes that contain live pathogens or their toxins & 400.0 & $\begin{array}{l}6 \text { times a week } \\
\text { (from Monday to Saturday) }\end{array}$ \\
\hline 180104 & $\begin{array}{l}\text { Non-infectious waste (e.g. dressing material, plaster, } \\
\text { linen, disposable clothing) }\end{array}$ & 4.0 & Followed by telephone order \\
\hline $180106^{*}$ & $\begin{array}{l}\text { Chemicals, including chemicals, containing hazardous } \\
\text { substances }\end{array}$ & 0.5 & Followed by telephone order \\
\hline $180108^{*}$ & Cytotoxic and cytostatic drugs & 8.0 & 5 times a week \\
\hline 180109 & Drugs other than 180108* & 1.0 & Followed by telephone order \\
\hline $180182^{*}$ & Food remnants from infectious wards' patients & $\begin{array}{l}6 \text { times a week } \\
\text { (from Monday to Saturday) }\end{array}$ \\
\hline & & 4.5 & 425.0 \\
\hline
\end{tabular}


(codes 160602*, 160604, 200133*, 201034), used tires (160103), oily wastes (sorbents, filters - code $150202^{*}$ ), gases in containers (fire extinguishers -code 160505), packaging containing residues of hazardous substances (code 150110*), electrical and electronic waste (codes 160211*, 160213*), magnetic and optical media (code 168001). Unsorted municipal waste collected are kept in containers with a capacity of $1.1 \mathrm{~m}^{3}$ and a container KP-7. These wastes from containers of $1.1 \mathrm{~m}^{3}$ are received every day, 6 days a week. For the period February 2015 - February 2016 the estimated number of emptied containers is 4250 units, and KP-7 containers - 50 units [Disposal... 2015]. Dry fraction of municipal waste is collected on a regular basis in containers of $1.1 \mathrm{~m}^{3}$ (the number of emptied containers a year: 220 units), and in periods of increased collection, in KP-10 ECO container (number of containers emptied during the period assessed 50 units). The remaining segregated wastes are set in the hospital, from time to time depending on the needs for appropriate containers.

Part of the non-medical waste management system which requires a constant improvement is recycling of municipal waste. The key to improving waste management in this field is to selectively collect the largest possible amount of useful waste fractions at source. One might consider implementing a solution of multi-fraction selection of secondary raw materials from waste, i.e. waste of paper and cardboard (code 150101), plastic packaging (code 150102), metal packaging (code 150104), glass packaging (code 150107) and their direct sales to an external entity for recycling. Additionally, baling recyclable materials (paper and cardboard, plastics), facilitate their storage and affect lower transport costs. The adoption of such a solution, however, involves the expenditure for the purchase of a baler.
An initiative improving waste management in the hospital would be selective collection of organic kitchen waste and transferring them to entities involved in the processing of waste into valuable compost. Such waste could be collected in sealed containers with a capacity of 100-120 litres and received at a frequency determined by the hospital, e.g. 3 times a week. The company that provides such a service could additionally provide a rental service, cleaning and disinfecting the containers.

Optimizing the operation of the hospital management of segregated, solid and susceptible to crushing municipal waste (code 200301) would be to use press-containers to their collection, instead of $1.1 \mathrm{~m}^{3}$ containers. For example, in a filled press-containers MPC5 P/E of compression force about $210 \mathrm{kN}$, the weight-average municipal waste is $1150 \mathrm{~kg}$ [Reception... 2015]. To determine the annual cost of waste collection collected in a presscontainer with a capacity of $5 \mathrm{~m}^{3}$, the data on the number of press-container emptied during the year and the unit price of exports are needed. Table 4 presents, for the assumed data, a calculation of the costs associated with receiving the same amount of mixed waste collected in a container of $1.1 \mathrm{~m}^{3}$ and a press-container of $5 \mathrm{~m}^{3}$. The calculations takes into account the amount specified by the hospital emptied containers of $1.1 \mathrm{~m}^{3}$ in the year of 4250 pieces. An important task is to collect and analyse data on the degree of filling containers per day. The results of the analysis will be used to verify the required number of containers for collecting waste. In case that you need a smaller number of containers than before, then there are two possible options for solutions. At first, a fewer number of containers used with an unchanged frequency of their reception was assumed. In the second case the same number of containers was assumed, but the collection will take place less frequently, for example, three times a week, instead of six.

Table 4. Annual costs of collection, transport and management of mixed waste (code 200301), depending on the type of containers

\begin{tabular}{|l|l|c|c|}
\hline \multicolumn{1}{|c|}{ Type of container } & \multicolumn{1}{|c|}{ Parameter } & Unit & Amount \\
\hline \multirow{5}{*}{ Containers $1.1 \mathrm{~m}^{3}$} & $\begin{array}{l}\text { Number of containers (reception every day for 6 } \\
\text { days a week) }\end{array}$ & Item/year & 4250 \\
\cline { 2 - 4 } & Cost of collection and disposal per unit & PLN/item & $47.54^{*}$ \\
\cline { 2 - 4 } & Cost per year & PLN/item & 202045 \\
\hline \multirow{3}{*}{ Press-container $5 \mathrm{~m}^{3}$} & $\begin{array}{l}\text { Number of press-containers (reception 3 days a } \\
\text { week) }\end{array}$ & Item/year & 156 \\
\cline { 2 - 4 } & Cost of collection and disposal per container & PLN/item & $720^{* *}$ \\
\cline { 2 - 4 } & Cost per year & PLN/year & 112320 \\
\hline
\end{tabular}

$*$ - acc. [1]; **-acc. [8] 
The proper organization of waste collection allows to reduce the frequency of collection of waste and achieve environmental and economic benefits.

\section{CONCLUSIONS}

Systemic approach to the management of waste generated in the hospital is to perceive it as interrelated elements, forming a whole. The elements of the waste management system should be shaped to their functioning to increase the system efficiency while complying with legal requirements. To take action to improve the system it is necessary to analyze the existing system at the level of the organizational and logistics services. The system analysis on the organizational level allows to specify the tasks and responsibilities of people in the field of waste management and the flow of waste streams. The analysis of the system at the level of logistics technology provides information on the status and needs in the field of technical measures and infrastructure.

The analysis of the basic elements of the waste management system emerging in the Clinical Hospital No. 4 in Lublin allowed to formulate the following conclusions. It is economically reasonable for the hospital to reduce the frequency of receiving medical waste coded $180103^{*}$ and $180182^{*}$ from 6 to 3 times a week. In practice, this would require to allow temporary storage of far more waste. Legal requirements must be met, according to which waste can be stored at a temperature of $10^{\circ} \mathrm{C}$ to $18^{\circ} \mathrm{C}$ for $72 \mathrm{~h}$ and at a temperature below $10{ }^{\circ} \mathrm{C}$ - up to 30 days [Project... 2015, Regulation... 2010]. The adoption of such a solution may involve expenditures on infrastructure and technical equipment for storage rooms.

Part of the non-medical waste management system, which requires continuous improvement is to increase the level of recycling of usable fractions of municipal waste. To do this, you can consider implementing a solution that enables hospital multi-type selection of secondary raw materials from waste and their direct sales to recycling companies. To facilitate storage and reduce the transport of recyclables it would be reasonable to compress these fractions with a baling press. For the realization of this task, the hospital must provide financial resources.
In order to improve the efficiency of waste management system, it is reasonable to organise selective collection of organic kitchen waste and forwarding them for processing into full-value compost. To properly organize the management of waste, quantitative research is needed. In order to optimize the operation of unsorted, solid and susceptible to crushing municipal waste management in the hospital a press-container for their collection could be applied instead of the currently used containers.

\section{REFERENCES}

1. Price list of waste collecting company MPO Sita Lublin Sp. z o.o.; www.mposita.lublin.pl/cennik01072012.pdf (access: 12.07.2012).

2. Marszelewski M., 2014. Gospodarowanie odpadami medycznymi i weterynaryjnymi w ustawie o odpadach. Przegląd Prawa Ochrony Środowiska 2, 77-100.

3. Reception, transport and disposal of medical waste, hazardous and non-hazardous municipal waste and biodegradable kitchen waste. SIWZ 2/15 / ZP (3/2/2015). Healthcare facility in Dabrowa Tarnowska

4. Project of 23 January 2015 of the Regulation of the Minister of health on the detailed handling of medical waste.

5. Regulation of the Minister of Health of 30 July 2010 on the detailed procedure of medical waste management. OJ 2010 No. 139, item. 940.

6. Regulation of the Minister for the Environment of 9 December 2014 on waste. OJ 2014 item. 1923.

7. Regulation of the Minister of Health of 24 July 2015 on the types of medical waste and veterinary waste whose recovery is permitted. OJ 2015 item. 1116.

8. Junk Revolution - declaration, models and documents needed for its fulfillment, http:/www.miejska-gorka.pl/pl/10864/108919/(access:25.02.2016).

9. Suchecka J, Twardowska K., 2014. Zarządzanie logistyczne odpadami medycznymi. Logistyka 5, 2091-2098.

10. Collection, transport and disposal of medical waste to be submitted by Teaching Hospital no 4 in Lublin. BIP SPSK No. 4 in Lublin, EDZ.242$49 / 2015$.

11. Disposal of municipal waste from the Teaching Hospital No. 4 in Lublin. BIP SPSK No. 4 in Lublin, EDZ.242- 21/2015.

12. The Act of 14 December 2012 on waste. Dz. U. 2013 item. 21 with amend. 